\title{
Exploring the Path of Cultivating College Students' Personal Morality in Ideological and Political Theory Courses
}

\author{
Jianhua Hu1 ${ }^{*}$, Xinting Zhou ${ }^{2}$ \\ ${ }^{1}$ School of Marxism, Qinghai University, Xining 810016, Qinghai Province, China \\ ${ }^{2}$ School of Finance and Economics, Qinghai University, Xining 810016, Qinghai Province, China \\ *Corresponding author: Jianhua Hu,672446283@qq.com
}

Copyright: (C) 2022 Author(s). This is an open-access article distributed under the terms of the Creative Commons Attribution License (CC BY 4.0), permitting distribution and reproduction in any medium, provided the original work is cited.

\begin{abstract}
Based on the demand of social development for people with both ability and political integrity, it has been acknowledged that some college students have a problem, where their personal morality does not match their professional knowledge. In short, these students have rich and profound professional knowledge, but their personal morality is lacking. Therefore, the attention to such a problem is called for. This paper analyzes the path of cultivating college students' personal morality in ideological and political theory courses in the new era, combs and expounds the occurrence mechanism between college students' personal morality and ideological and political theory courses in the new era, improves the effectiveness of moral cultivation in ideological and political theory courses from four dimensions - teaching materials, teachers, teaching methods, and evaluation, as well as gives full play to the moral cultivation function of ideological and political theory courses in colleges and universities.
\end{abstract}

Keywords: Ideological and political theory courses; College students; Personal morality

Online publication: January 20, 2022

\section{Significance of cultivating the morality of college students}

Morality, as understood, has the same concept as "ethics," "virtue," and "moral character." It is intangible but exists in everyone. It is the inner state or psychological characteristics of an actor expressed through one's behavior ${ }^{[1]}$. The relationship between virtue and morality is a general and special relationship. Hegel believes that morality is the embodiment of ethical principles and general norms in personality. He once pointed out, "Virtue is the ethical order reflected in the individual character so far as that character is determined by its natural endowment ${ }^{[2]}$." Morality is the symbol of an individual's moral realm, which is closely related to the development of personality and moral psychology. Morality is the unique disposition, temperament, and ability of individuals to understand, internalize, and practice the general principles of ethics and the universal norms of morality.

\subsection{Promotes social development and progress}

In the whole moral construction system, compared with the construction of social morality, professional morality, and family virtue, personal moral construction has more significance. In other words, personal moral construction is the foundation of all moral construction. The world is undergoing profound changes 
that have not been seen in centuries. In the next 30 years, it is necessary to train people to accomplish the "two centenary goals." This is the historical responsibility of education. In the long historical process of human society, talents have always been the builders and promoters of social development as well as civilization progress. In the 21st century, with the rapid development of knowledge economy and the increasing socialization and globalization of human resource allocation, talents have become the impetus and the most important resource for social progress and economic development. A man without virtue cannot go far. Without good moral character and ideological cultivation, even if one has abundant knowledge and profound learning, one will not achieve great success. Talent cultivation, which is fundamental, must include the unification with people's education.

In general, the mission shouldered by contemporary college students puts forward high requirements for quality in all aspects. In order to accomplish the historical mission of contemporary college students, it is imperative to carry out comprehensive development. Only by cultivating one's own quality and skills comprehensively in all aspects can one accomplish the mission with ease and make due contributions to the cause of the great rejuvenation of the Chinese nation.

\subsection{Promotes people's all-round development}

In the process of continuous evolution and development of human history, people have different views and opinions on the proposition of human development in different periods. On the basis of reality, through the dialectical theory and practical research methods of historical materialism, Marx further analyzed human thought based on the French utopian socialism theory and put forward a new theory where man will eventually realize free and all-round development. Based on practice, the theory of all-round development of human beings, which reveals human essence, points out the direction for human development. Marx's theory mainly includes four aspects: the all-round development of human being's personality, the all-round development of human being's quality and ability, the all-round development of human being's needs, as well as the all-round development of human being's social relations ${ }^{[3]}$.

The all-round development of human beings mandates the all-round development of people's comprehensive quality. Therefore, it can be deduced that people's all-round development refers to the improvement of people's personal morality. Personal morality plays a commanding and guiding role in the process of people's all-round development, and it is also one of the core indicators of a person's all-round development. Therefore, it is necessary to pay attention to the function of ideological and political theory courses to improve students' personal morality. The main reason for the problems in social development is that that people's comprehensive quality is low, and the depth and breadth of understanding of all aspects are inadequate, thus leading to various problems restricting the all-round development of human beings.

\section{Analysis on the occurrence mechanism of cultivating college students' personal morality in ideological and political theory courses}

In regard to the formation and development process of people's ideology and morality, the "Principles of Ideological and Political Education" holds that people's ideological and moral character is neither determined by subjective factors alone, nor the reflection of objective external factors on individuals, but rather the product of the interaction of subjective and objective factors in the process of subject practice. The formation and development process of ideological and moral character is the dialectical and unified process of external restriction and internal transformation ${ }^{[4]}$. Among the external factors, school education is more instructive to the cultivation of people's morality. Therefore, through the educational influence on college students from the dimensions of teaching materials, teachers, teaching methods, and evaluation in ideological and political theory courses, the morality of college students has changed internally. 
By reading relevant materials, the formation process of ideological and moral character is actually a process of dialectical and balanced development of people's internal factors, which include knowledge, emotion, will, faith, and action, under the influence of certain external environmental factors ${ }^{[5]}$. When the social moral requirements represented by ideological and political theory courses are reflected in the main ideology of college students, there will be a contradictory movement within the original internal moral structure of college students; in addition, there will be a dialectical movement in the ideological and moral cognition, emotion, will, belief, as well as behavior of college students. This process is manifested in a cyclic movement: "external influence $\rightarrow$ subject accepts external influence through activities and communication $\rightarrow$ ideological contradictory movement $\rightarrow$ formation of internal moral environment ${ }^{[6]}$." Through teaching materials, teachers, teaching methods, and evaluation, ideological and political theory courses have an external impact on college students from different dimensions and promote the internal moral transformation of college students, thus ultimately leading to the formation of a personal moral state that meets the requirements of social development; that is, to enable college students to meet the personal moral requirements of "patriotic dedication, courtesy and compliance, diligence and kindness, generosity and integrity, as well as self-improvement and self-discipline" and form a sound moral knowledge system, positive emotional identity, firm moral will, lofty beliefs, as well as correct moral behavior.

Although the four dimensions have an external educational impact on college students' morality, their impact on college students' personal morality is different; as the carrier of moral knowledge, ideological and political teaching materials contain rich content about personal morality; as the main body in ideological and political teaching and the guide for students' growth, ideological and political teachers carry important emotional value for the shaping of students' morality; as an important link in the development of ideological and political classes, ideological and political teaching method is the key process for college students to transform moral knowledge into moral behavior; as an important index to measure the effectiveness of the function of ideological and political theory courses to cultivate morality, political theory course assessment and evaluation plays an important guiding role in personal moral cultivation. Through the moral education of college students in different dimensions of ideological and political theory courses as well as college students' active learning and practice after education, they will be able to effectively improve their personal moral status and ensure their personal morals meet the moral requirements of the new era.

\section{The path of cultivating college students' personal morality in ideological and political theory courses}

\subsection{Integrate textbook resources and enrich the content of personal moral cultivation}

First, it is necessary to integrate ideological and political teaching materials with teaching materials from other resources. The function of the ideological and political course textbook is to provide a knowledge system for the course; the second is to provide teaching materials for teachers; the third is to provide students with a knowledge base for learning. Therefore, for ideological and political teaching and learning, teaching materials should be assumed as the starting point. As teaching materials are for students to learn, these materials should adhere to the "student-centered" concept. The readability, popularity, and knowledge of teaching materials have an impact on students' self-learning, understanding, and mastery of basic viewpoints and important contents. Therefore, in view of the deficiencies in the teaching materials, it is necessary to improve the content and optimize logic to meet the needs of teachers for lesson preparation as well as students for self-learning and reading, so as to continuously enhance the effectiveness of teaching.

There is no doubt that teaching materials should include the national unified compilation of teaching materials and other guidance materials, which represent the unity of teaching materials and the diverse development requirements of the times. The unified textbooks used by colleges and universities across the 
country are the basis for the country's ideological and political courses. The logical rigor of the textbooks indicates that they can only be understood through rational thinking. This means that the so-called "downto-earth" and "easy to understand" requirements proposed in textbooks are unreasonable because these requirements are contrary to the fundamental nature of teaching materials ${ }^{[7]}$. Secondly, there are other teaching materials, which do not only include local textbooks of colleges and universities in the regions where they are located, especially those in ethnic minority areas, and current political textbooks that closely follow national political life and current affairs, but also digital textbooks based on the network as well as social practice teaching textbooks. With the continuous development of society, the textbook system is constantly enriched. In today's ideological and political education, it is no longer a just single textbook, but a combination of multiple textbook resources.

Second, it is necessary to enrich the moral education content of ideological and political teaching materials. The constant integration of new teaching materials is the key to realizing ideological and political education in ideological and political courses for the cultivation of college students' personal morality. The ideological and political course textbook standardizes people's thoughts and behaviors. It has a guiding and ideal value for the growth of college students. It "edifies" in morality, points to "enlightenment" and "moralization" in behavior, and then directs people's personality development and spiritual freedom with purpose. From a survey, it has been acknowledged that students prefer novel and interesting teaching materials and contents. The teaching materials of ideological and political courses are not able to fully meet the needs of students, so they need to be supplemented by other teaching materials. The moral education content in unified textbooks is the most complete; local textbooks highlight regional characteristics and moral education content can be added according to the actual situation of the region where the university is located, such as ecological ethics and national ethics; patriotic education and political guidance to social problems and events can be added in the current politics textbook. This method has achieved excellent results in the teaching reform of ideological and political courses. Many students are fond of the knowledge and moral experience brought by ideological and political courses.

As a matter of course, the content needs to be taught by teachers in classrooms. Therefore, the important role of teachers, teaching, as well as the assessment and evaluation should also be emphasized.

\subsection{Improve teachers' quality and enhance the effect of personal moral cultivation}

The quality of ideological and political teachers is of great significance to ideological and political teaching. Teaching is a process in which teachers actively reprocess and recreate teaching materials. Ideological and political teachers should ensure that the teaching contents are close to reality, life, and the students, in order to promote the interaction between theory and reality as well as guide students to understand the knowledge and ideas behind the teaching materials. Due to different teaching experiences, ideological and political teachers have different degrees of understanding of the content, which would affect the understanding of certain curriculum contents and the final effect of moral education.

First, it is necessary to improve teachers' teaching ability. In fact, the ideological and political course is a theoretical course that includes ideological guidance in its teaching. The characteristic of theoretical course teaching is to educate students with the power of truth, reason, and sense. Nowadays, there are students who regard ideological and political courses as leisure courses or homework courses of other subjects. This requires ideological and political teachers to improve their teaching ability, fully grasp students' ideological and theoretical confusion, as well as understand the students' interests. On this basis, teachers should take students' concerns as the starting point, and then use theory to analyze and solve students' ideological problems, so that they can learn and gain something, and the pertinence of ideological and political theory teaching can be effectively improved. Nowadays, with the continuous improvement of the state's attention to ideological and political courses, the teaching ability of ideological and political 
teachers has attracted much attention from academic circles. As a result, the teaching ability of ideological and political teachers is improving, which effectively improves the students' cognition of the importance of morality and enhances the function of ideological and political courses in moral cultivation.

Second, it is necessary to improve teachers' professional ethics and personal virtues. The responsibility of a teacher is to teach and educate people. The overall quality as well as the ideological and political level of college students are affected by the professional ethics of ideological and political teachers.

Some teachers teach very seriously but lack communication with students. They regard teaching solely as a task; thus, there is a lack of real respect and care between teachers and students. An ideological and political teacher with good professional ethics should not only pay attention to self-cultivation or improving his or her teaching skills, but also on strengthening the moral construction of students. Improving the professional ethics of ideological and political teachers in colleges and universities is an important measure to establish high-level ideological and political teachers. At present, strengthening and improving the professional ethics level of ideological and political teachers in colleges and universities is mainly carried out from two aspects: the external control of colleges and universities as well as the internal constraints of ideological and political teachers. On the one hand, practical rules and regulations should be formulated to standardize the professional ethics of ideological and political teachers in colleges and universities; the supervision and control mechanism in the construction of the professional ethics of ideological and political teachers should be improved and innovated; in addition, a fair and reasonable assessment system of professional ethics for ideological and political teachers should be established. On the other hand, the communist belief of ideological and political teachers should be strengthened; their political literacy should be improved, and their professional literacy should be enhanced; their sense of ownership should be strengthened along with their self-construction ability in professional ethics. An ideological and political teacher should have good morality, consciously act as an example, and be someone who is loved by students, so as to impart virtue and inspire students with truth. From the words used and behavior of a teacher, students are able to perceive the teacher's morality. From the introspection, students can then consciously develop good morality.

\subsection{Reform the teaching methods and clarify the value of personal moral cultivation}

First, it is necessary to combine theoretical indoctrination with practical teaching. The traditional ideological and political teaching focuses on theory rather than practice. This may cause a mismatch between theoretical knowledge and behavior. Theory is the guide of behavior. A correct theory is the crystallization of human wisdom, and it prevents detour. Therefore, in order to cultivate the morality of college students in ideological and political courses, it is important to adhere to the indoctrination of moral theory to alert the students of what is right and wrong. With the advancement of ideological and political course reform, practical teaching has been adopted by many colleges and universities. Practical teaching helps students shift from books to practice and guides students in such a way to care more about social reality, observe the social development of the new era with their own eyes, perceive the spirit of morality with their own thoughts, and practice moral ideas with their own hands.

Second, it is necessary to promote the innovation of teaching methods for moral education in ideological and political courses. Teaching is divided into teacher's "teaching" and student's "learning," but eventually, it must come down to the latter. Therefore, various innovative teaching methods for moral education should be adopted in the reform of ideological and political courses, so as to improve students' acceptance and practice of moral education. In ideological and political courses, it is important to highlight the status of students and encourage students to participate in classrooms. Ideological and political teachers can use various forms of in-class activities to mobilize students' initiative to participate. Teachers should guide and summarize, enhance the assessment and evaluation proportion of activities, allow students to 
experience the charm and value of morality in classroom activities, as well as enhance the endogenous power of students' morality.

\subsection{Improve the assessment and evaluation as well as form a guidance for personal moral cultivation}

First, it is necessary to optimize the evaluation contents and methods of ideological and political courses. The assessment and evaluation of a course is related to the students' views on the course. Among other professional courses, it is more likely that students' knowledge mastery is assessed as it is easier for the final assessment. However, in addition to assessing students' mastery of knowledge, assessing the development of students' ideas, political views, and moral norms in ideological and political courses is more important at this stage. Therefore, diversified evaluation contents and developmental evaluation methods should be adopted to increase students' sense of acquisition in ideology and morality.

Second, it is necessary to promote students' moral practice. Commonly, students' fondness for a course is evaluated. The most direct and simple evaluation is the students' sense of "harvest" after going through the course. Compared with other courses, many students think that the sense of acquisition from ideological and political courses is low due to poor timeliness. Students' learning is purpose-oriented, and timeliness is very important for them. Unlike mathematics and English, ideological and political courses allow students to solve problems immediately after learning a knowledge point. Therefore, the assessment and evaluation of ideological and political courses should strengthen the assessment of students' practice, promote students to verify moral knowledge in practice, "harvest" social value in practice, and deepen students' moral practice.

\section{Disclosure statement}

The authors declare that there is no conflict of interest.

\section{References}

[1] Sun Y, 2001, Morality and Virtue: Conceptual Debate. Journal of Shanghai Normal University (Philosophy \& Social Sciences Edition), 2001(02): 25-31.

[2] Hegel, 1961, Principles of Philosophy of Law, Commercial Press, Beijing, 168.

[3] Zhang L, Hu J, 2020, The Cultivation Path of College Students' Morality from the Perspective of Marx's Theory of All-round Human Development. Shanhaijing: Cutting Edge Education, 2020(35): 0016-0017.

[4] Chen W, Zhang Y, 2015, Principles of Ideological and Political Education (Third Edition), Higher Education Press, Beijing, 126.

[5] Chen W, Zhang Y, 2015, Principles of Ideological and Political Education (Third Edition), Higher Education Press, Beijing, 128.

[6] Chen W, Zhang Y, 2015, Principles of Ideological and Political Education (Third Edition), Higher Education Press, Beijing, 131.

[7] Wu H, 2021, Theoretical Consciousness of Teaching Material View of Ideological and Political Theory Course. Ideological \& Theoretical Education, 2021(06): 26-31.

Publisher's note

Bio-Byword Scientific Publishing remains neutral with regard to jurisdictional claims in published maps and institutional affiliations. 